Scientia Militaria vol 40, no 3, 2012, pp.398-428. doi: 10.5787/40-3-1028

\title{
The South African Defence Force and Horse Mounted Infantry Operations, 1974-1985
}

\author{
Jacques J.P. de Vries ${ }^{\bullet}$, Sandra Swart ${ }^{\star}$
}

\begin{abstract}
The South African Defence Force (SADF) made effective use of the horse mounted soldier in the Namibian Independence War or 'Border War', 1966 to 1989 , in Namibia (South West African) and Angola, in a conflict usually depicted as a series of high profile mechanised infantry operations. Nevertheless, the legacy of the horse-mounted infantryman of the South African War era commando was evident in this unit, which proved competent in the counter-insurgency patrol in the Area of Operations, and subsequently domestic deployment during civilian struggle during the State of Emergency. This article offers an exploration of the Potchefstroom Equestrian Centre's contribution to horse and rider training and the military use of horses in counterinsurgency and urban peace enforcement operations in the period c.1974-1985.
\end{abstract}

Keywords: Equestrian, horse, mounted unit, Equestrian Centre Potchefstroom, Border War

\section{Introduction}

Over the last century, from the creation of the Union Defence Force in 1912, the South African Defence Force (SADF) was predicated on horse power, both literal and increasingly figurative, in the military machine. ${ }^{1}$ This historical lineage survives in semantic remnants, with units still bearing their equine heritage in their titles, like the Transvaal Horse Artillery, the Umvoti Mounted Rifles, Natal Mounted Rifles and the Light Horse Regiment. The

- $\quad$ Erasmus Mundus Global Studies Masters, University of Leipzig.

- Department of History, University of Stellenbosch, 
horse and soldier did not fade to the ceremonial background as may have been the case in other armed forces, but instead retained usefulness on the frontlines of the Namibian Independence Struggle or - in the vernacular 'Border War' ${ }^{2}$ in Namibia (South West Africa) and Angola. The establishment of a specialised unit in the form of SADF Equestrian Centre for training and preparation of horses and National Servicemen in mounted infantry warfare at Potchefstroom in 1974 saw the reinvention in an equine military culture that was to continue right up until 2009, with the end of the SANDF (South African National Defence Force) Commando System and its role in rural sector security enforcement. The closing of SANDF Equestrian Centre Potchefstroom and handing over of the SANDF's horse mounted role to the South African Police Service, saw the end of the active use of the horse mounted soldier in the SANDF. Although, as this paper will conclude, this role may be revived in the current South African context.

Utilising unit documents from the archives of the South African Department of Defence in Pretoria, and oral history interviews with military veterans of the SADF and SANDF who served both in the training and combat domains, this article analyses the horse mounted infantry, within the context of SADF Equestrian Centre Potchefstroom's contribution from 1974 in counter-insurgency operations in the Areas of Operation, and in the socalled "township uprisings" of the State of Emergency from 1985. ${ }^{3}$ The SADF was restructured to meet the stringent needs of the new 'total strategy' and 'total war', and logistical capacity adjusted to provide for it. Yet when P.W. Botha's 'total war' came 'home' during the civil unrest in informal settlements from the mid-1980s, much of the cooperation between the SAPS and SADF was described as designed to check the escalation of politically motivated violence before its intensification spread nationwide and destabilised the domestic economy. The use of overwhelming force within the borders of the Republic was argued to be strategically politically counter-productive and the mounted horse had to shift function. Thus the article considers both of these operational areas and periods to explore the shifting and mutable use of horses within a military context.

\section{SADF Equestrian Centre, c.1964 to 1975}

Historically, Potchefstroom was itself a military garrison and depot springboard for the co-ordinating and launching of South African operations 
that would assist in wresting control of South West and later on East Africa from Imperial Germany during the First World War. The invasion of German South West Africa was spearheaded in part by horse mounted columns and ox-wagon trains. A key impetus behind the establishment of the SADF Equestrian Centre at Potchefstroom can be traced to 1968, when Magnus Malan assumed command of the Military Academy at Saldanha in the Western Cape. His instructions were to ensure that officer candidates of the Defence Force who showed potential become trained with particular emphasis on possible military operations in Namibia. ${ }^{4}$ Malan modified the contents of the three year B.Mil degree offered at the Military Academy to encompass not only formative and tertiary training but also specifically focus on "leadership abilities", and believed horsemanship provided a challenge for candidate officers in this regard. He argued for the advantages of utilising horsemanship to encourage flexibility for officers under more basic, low-technology circumstances. He envisaged a greater role for horses on the border, and during his time as Chief of the Army, believed very strongly in the impact which horse mounted troops had against insurgents, who, Malan contended, "feared [horses] more than tanks or guns in South West Africa". There is a long history behind this. Horses were first introduced into southern Africa as a form of enhanced mobility for settlers and soldiers, and served as weapons of psycho-social terror, indeed as the seventeenth-century equivalent of 'shock and awe'. Van Riebeeck was gratified that the local population seemed cowed, awestruck by the 'miracles' of speed the horses performed. This laid the foundation for horses as symbolic display of power that has persisted. As Storey has observed of guns, a 'new order is made out of a demonstration'. The symbolic display went hand in hand with the practical deployment of horses in the pursuit and maintenance of material power. ${ }^{6}$

On 1 April 1964 the SADF Dog School was established at Voortrekkerhoogte $^{7}$ in Pretoria and in November of the same year was expanded to encompass control over all matters relating to horses in the SADF. From 1 April 1971, it was re-designated the SADF Horse and Dog Centre. $^{8}$ This unit was decommissioned on 1 April 1974 and replaced by two separate units, one of which was to become the 'Equestrian Centre'. ${ }^{9}$ Its primary functions were to breed, break-in, and train horses, and also to train SADF personnel in military horsemanship. ${ }^{10}$ By 1973 it had become accepted that there was indeed an operational requirement for an equestrian 
school, and in January 1974 the first Commandant, Gert Opperman, commenced with the ground-breaking of the new unit on the farm Welgegund outside Potchefstroom. ${ }^{11}$ After an intense and rapid training period, its first mounted troops were deployed to the Border region by September of the same year. ${ }^{12}$

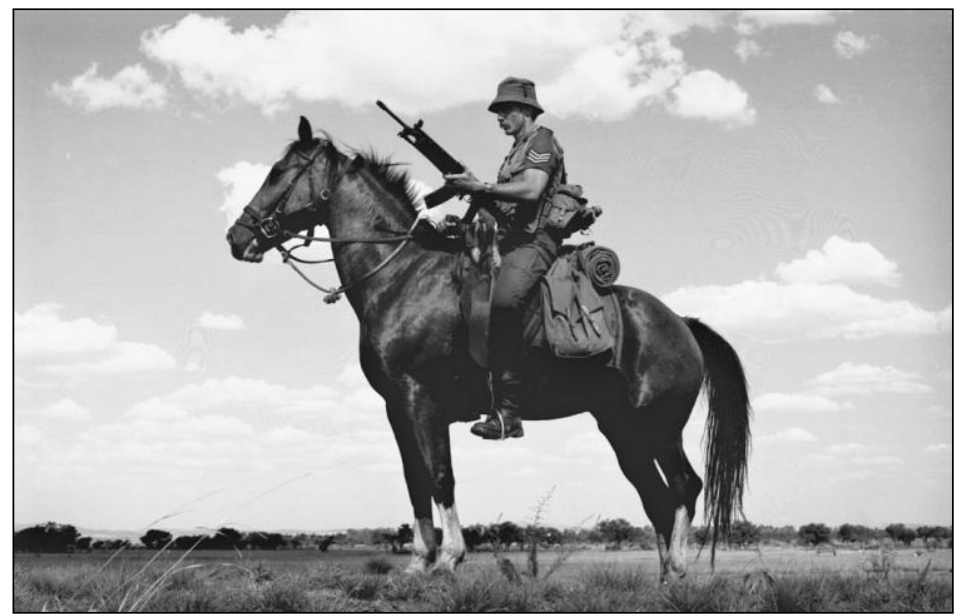

Figure 1: Mounted sergeant in full patrol kit, webbing, saddle bags, sleeping bag, and R4 rifle. [Source: DOD Archives. Image 871000265: aanwending van perde deur die saw.]

\section{In the saddle: Equestrian Schooling for National Servicemen and their Horses}

According to Warrant Officer Class 1, "Jakkie" Nagel, a Regimental Sergeant Major, in the eyes of the Defence Force, officially the horse was a mode of transport from point A to point B. Yet, unofficially, the relationship between the mounted infantryman and his horse extended far beyond this. On deployment in the Operational Area this horse was the closest thing the national serviceman had to family, other than his fellow conscripts. ${ }^{13}$ Indeed, Nagel argued that while the horse was a soldier's transport, it was also "his friend, his everything". ${ }^{14}$ 
Conscripts deployed to the equestrian branches of the South West Africa Specialist unit (SWASpes) ${ }^{15}$, South West Africa Territory Force (SWATF) and later in the Pretoria Witwatersrand Vereeniging (PWV) region during the State of Emergency, did so for the most part with the horses they had schooled at the SADF Equestrian Centre. The mounted troops began National Service in the conventional way, finishing basic training first before specialisation as mounted infantry. Twenty one weeks were spent on basic horsemanship, mounted weapons training, and COIN (Counter-Insurgency) ${ }^{16}$ mounted tactics. Most of the horse mounted infantrymen would use their "own" familiar horse exclusively on patrols to consciously cement an intimate emotional bond. The thinking was that this would forge a close partnership, in which mutual trust, support, concern and even potential grief for the horse was equal to that shown to fellow (human) soldiers. ${ }^{17}$ The men who were assigned to this unit were deliberately drawn from those tested as possessing a strong affinity for animals. Moreover, they were often from agrarian backgrounds, and thus familiar with the rigours required for this particular job. To further forge a close relationship between soldier and horse, the conscript's responsibilities extended not only to maintaining but also grooming, stabling and feeding his own charge, over and above his general duties as a soldier. ${ }^{18}$ This was reinforced by the psychology of training, serving to reinforce identification with the horse. As one soldier remembered:

We were [at first] BANNED from riding. The closest we came was when we had to clean our horses. [But] two "maatjies" (buddies) took a fat chance. They were riding their horses bareback between the stables. One of the corporals was walking around when he noticed our two heroes having a very merry time on horseback. "Wil julle perdry?" (Would you like to ride?) he enquired. "Ja asseblief" (Yes please) they gladly responded. "Gaan haal julle saals en tooms" (Go and fetch your saddles and bridals). ... "Saal op" (saddle up) said the corporal. As they started moving towards their horses, he said "Waar Gaan Jy?" (Where are you going?). "Maar Korporal het gese ons moet opsaal" (But, corporal, you said we must saddle up.) " Nie die perde nie, jou maatjie"(Not the horses, your buddy.) They both adopted looks on their faces that's reminiscent of a slapped bum. "Hoe nou?" (How now?) they enquired, so he showed them. He saddled up one guy and put a bridal [sic] in his mouth and then he made his "maatjie" (buddy) ride him. They really "Kaked af" (Shat off) that day, but by the end of it they had a really good idea of what a horse feels like $e^{19}$. 
If you've ever ridden a horse for a protracted period of time you will know that there is lots of spit and grassy type of cud in the horse's mouth. This had hardened on the snaffle [bit]. "Wat is dit die?"(What is this?) The corporal enquired "Spoeg" (Spit) came the reply. "En jy wil dit in jou perd se bek sit? Lek!" (And you want to put this in your horse's mouth? Lick!). He gingerly extended his tongue and very delicately licked the dirty snaffle. "So!" (Like this!) Growled the corporal shoving the bit into the man's mouth. I saw his face go the colour of the grassy cud he was licking. This was the quickest way to get us to make sure our bits were cleaned after riding. ${ }^{20}$

To many of those stationed at Potchefstroom who received training there, the riding instructor Peter Stark was the epitome of Equestrian Centre training, though the individual himself said shortly after his retirement on 30 April 1989 that the highlight of his term at the unit was simply satisfaction he gained from the subsequent national sports successes of individuals whom he had instructed in advanced riding art. ${ }^{21}$ Stark was promoted from his rank of Lance Corporal attained during his National Service to Major at the establishment of Equestrian Centre and then to Commandant of its equitation wing in one of the most rapid rank-bounds in the history of the Defence Force. As a founder father of Equestrian Centre he went from being a notorious game poacher in SWA to assuming the position of chief game ranger and tracker in the Etosha National park after being offered the post when authorities could not curb his lucrative but illicit activities. ${ }^{22}$ The "if we can't beat him, ask him to join us" approach was also adopted by the Defence Force and, in 1974, General Johannes "Jannie" Geldenhuys, chief of the SADF and General Magnus Malan, then Minister of Defence sought out his expertise in the establishment of Equestrian Centre. ${ }^{23}$

The second commandant at Equestrian Centre, Major Albert van Driel, accepted the challenge of formulating operational doctrines for horse mounted battlefield roles and methods, and for the employment of mounted infantry in combat situations. A committee for the study of doctrinal proposals under Major Leon Wessels saw the proposals find practical expression. The findings of this committee were published in the SADF manual entitled Training and Employment of Mounted Infantry, shortly after van Driel's departure from the unit in $1977 .{ }^{24}$ At the time, this handbook was the only officially published literature within the SADF with reference to Mounted Infantry, espousing the need for specialised training and its application for mastering techniques such as riding skill, handling of 
weapons on horseback and teamwork between the horse and rider. ${ }^{25}$ During Colonel Leon Wessels' time at Equestrian Centre, the increase in internal violence in South Africa created a new opportunity for the application of horse mounted infantry in the urban COIN role. Wessels was responsible for much of the tactical doctrine refinement included in the Training and Employment of Mounted Infantry Manual of $1978 .{ }^{26}$ As will be discussed below, the mid-1980s saw a shift in the Unit's involvement in patrolling the border areas towards involvement in the urban unrest and rural counterinsurgency within the South Africa itself. ${ }^{27}$ Upon the handing over of command from Wessels to his successor, Commandant Nic Ackerman, in January 1985 , many of the doctrines concerning the use of mounted infantry were created almost from scratch and 'refined on the hoof' in the first three years of the unit's existence. Specifically those on the use of mounted units in the urban counterinsurgency role were tested for the first time in the mounted company deployments to the PWV townships. ${ }^{28}$

Van Driel's proposals found support among the generals at Army HQ. P.W. Botha, who was at that time the Minister of Defence, was a keen rider, had a personal interest in the SADF horse stud farm at De Aar, and was a close personal friend of Piet Marais, Chief of ARMSCOR, who also had a farm in Potchefstroom and, as a Colonel in the Reserves, had spent his time on Commando in the De Aar district where the Zevenfontein stud farm was located. ${ }^{29}$ Through their support and that of General Magnus Malan, there was a high ranking interest and thus concomitant political willingness to support Equestrian Centre. ${ }^{30}$

At first, in initial training and deployments, Equestrian Centre supplied standard issue civilian saddles that were not designed to take the strain exerted by excessive loads carried by an armed infantryman whilst in the saddle, namely rifle, ammunition, personal equipment, saddlebags containing feed and water, and the fatigue created by often riding in excess of twenty to thirty kilometres per day while on patrols. Soldiers were taught to ride, while carrying the long, heavy $7.62 \mathrm{~mm} \mathrm{R} 1$ assault rifle in one hand and keeping the reins only in the other hand (this weapon would later be supplanted by the lighter, more compact Israeli manufactured $5.56 \mathrm{~mm}$ Galil and South African made R4). Soldiers thus learned to direct their horses with their legs much more than their reins. ${ }^{31}$ The McClellan saddle, which in the domestic civilian sphere was a rugged utilitarian saddle used in farm 
work and cattle ranging in particular, proved best equipped for the heavy strain and was adopted after its recommendation to an Equestrian Centre fact-finding mission led by Van Driel to the Grey's Scouts of the Rhodesian army in $1975 .{ }^{32}$ Specialised vehicles were also developed to transport horses in the Operational Area, in which Equestrian Centre collaborated closely with engineers at ARMSCOR's subsidiary Mechem, leading to the development of mine-resistant horse transporters such as the Kwêvoël 10berth horsebox which incorporated the SADF's innovative V-shaped hull mine protection technology. ${ }^{33}$ Equestrian Centre staff members such as Quinton Painter visited to Chile's Army Cavalry School to take part in their "International Master of Equitation" programme and learn more of equestrian instruction. ${ }^{34}$

From the outset, recruits arriving at Equestrian Centre experienced accommodation and amenities conditions synonymous with border deployment even before leaving the confines of their training base in the Republic. ${ }^{35}$ Training areas at Wahlmanstal and Bloubos were used for instructing mounted troopers in rural COIN tactics and manoeuvres, and at Setlahole in the Northern Cape where the terrain and conditions best prepared trainees for conditions comparable to the SWA and Angola border. ${ }^{36}$ Novices would train on horseback in full operational $20 \mathrm{~kg}$ kit order, saddlebags full of horse food concentrate, rifle and ammunition, and "staaldak" $"$. They were trained to fire their weapons from the saddle and how to disembark from their mounts at full gallop with heavy kit. ${ }^{38}$ This would culminate in a three or four day, thirty five or forty five kilometre round trip ride from the base at Welgegund to Wahlmanstal and back. On this outride entitled "Blikners", the recruits suffered injuries, from saddle sores to calves rubbed raw, and more serious injuries resulting from falls, such as broken arms and legs, and sprained and dislocated shoulders. ${ }^{39}$ The individuals chosen to train at Equestrian Centre for service on patrol motorcycles and horses went through further training under strenuous conditions and were required to be in excellent health. Brigadier Gert Opperman, who was the first commanding officer at Equestrian Centre, observed that from "the very beginning, Equestrian Centre's units both at the main facility and in the operational areas had to subsist on a bare minimum. This was possibly the status quo due to the questioning and scepticism of the units' right to existence, and doubting of the cost effectiveness of the application of horses. ${ }^{40}$ There were few comforts at 
Equestrian Centre, with Jakkie Nagel stating to new candidates at orientations:

...listen men, we don't have warm water like you have here, we don't have barracks in which you sleep, we do not have a canteen where you eat, you're going to live in tents, you're going to shower with cold water some days, no luxury... ${ }^{41}$

In terms of the number of horses ready to train at Equestrian Centre, figures of around eight hundred and fifty mounts were present or being rotated in or out, while there may have been up to one thousand horses at the peak of Equestrian Centre operations. ${ }^{42}$ Boerperde and Arabians were favoured, where possible. There was a great deal of interaction and cooperation between Equestrian Centre, the Defence Force's South African Military Health Service (SAMHS) and its veterinarians, and prominent feed companies such as EPOL, who developed programmes to obtain the best balance of nutrition in feed cubes for horses under differing conditions, and developed new feed for mounted units to be used while out on patrols in the Operational Area. Training expeditions would be accompanied by EPOL personnel to their large COIN training operations in the North West Province at Stella. ${ }^{43}$ There, experimental as well as standard feed concentrate would be provided free of charge to the Defence Force by EPOL and given to horses in trial and control groups to measure the feed's benefit in the field, with blood samples, temperature, pulse and respiration measured daily by SAMHS veterinarians and nutritionists to determine the adaptation to new nutritional intake. ${ }^{44}$ These findings also culminated in the development and application of pre-packaged "horse rat [ration] packs" in specific, efficient nutritionally balanced effective measures and in weights which best suited the horse's day to day operational use. ${ }^{45}$

Water was the most critical necessity for the animal which the rider had to monitor. According to the Training and Employment of Mounted Infantry Basic Riding Instruction Manual, a horse requires on average between thirty to fifty litres of water per day. ${ }^{46}$ Without adequate provision of water the horse's blood circulation is affected as well as the effective functioning of its digestive system. ${ }^{47}$ While on long distance patrols the rider carried his usual complement of water bottles, though with the horse it was prudent to know the location of "shonas" ${ }^{48}$, local wells and watering holes 
belonging to the local population where the horses could be taken to quench their thirst. ${ }^{49}$ If this was not possible, radio contact could be made to rendezvous with Buffel and Casspir armoured personnel carriers that were already in the field that had enormous tap dispensable on-board water tanks. ${ }^{50}$ It was necessary to carefully plan patrol routes, laying down certain distances in the early hours of the morning while it was still cool, and then to camp temporarily during the hot midday hours to afford the horses a chance to rest and cool down, recommencing with the patrol in the late afternoon until a few hours before sunset. ${ }^{51}$ Depending on the nature of the patrol, one's function could transport in an instant if stumbling onto and chasing 'spoor ${ }^{52}$, since the swift pursuit of the enemy became of primary importance.

Horses need to eat - unlike military motorbikes and trucks - and they need to eat well - unlike regular soldiers. Of the telegrams and telexes from the Sector Two Zero area in the period 1979 to 1983 relating to management, a number of obstacles became apparent, particularly the spoilage of fodder at bases, the availability of logistics capacity in the form of vehicles and the loss of vehicles involved in landmine detonations during delivery of equine supplies to far flung units, and the supply of already spoiled feed provided by Defence Force contractors. ${ }^{53}$ Telegrams were sent by embattled satellite units to SWASpes command at Oshivello, such as the communiqué from 16 Support Unit ${ }^{54}$ containing urgent requests for the next date upon which feed would be delivered, since the unit had not received its regular consignment and that supplies were desperately low. This unit survived through the assistance of a nearby agricultural research station before the SADF logistical system was again able to supply it with feed. ${ }^{55}$ On 4 July 1981 a communiqué was sent by 53 SAI Bn. to SWASpes headquarters asking for the urgent despatch of a farrier to the outpost at Etalé due to the critical condition of horses' hooves there. Despite these challenges, demand for horse mounted patrols along the border increased to combat ever greater cross border infiltrations by the South West Africa People's Organization (SWAPO). 


\section{Counterinsurgency and SADF Horse Mounted Troops}

According to the Training and Employment of Mounted Infantry Manual, application of mounted infantry formations in the COIN role in rural areas included seven roles, namely the deployment of fighting patrols, seeking out signs of enemy activity and engaging in follow up operations to find and destroy them, secondly in follow up operations, pursuing enemy spoor because of the inherent speed in reaction of the horse ${ }^{56}$, thirdly as cut-off groups where coordinated movement of mounted units could be used in support of more conventional operations in stopping and cutting off fleeing enemy elements. ${ }^{57}$ Fourthly, they could be used in sweep and pursuit operations where the speed and mobility of the horse is better suited to covering large distances in search of the enemy. ${ }^{58}$ Mounted detachments could be used for reconnaissance, in this role every rider as part of a section or platoon on patrol would act as a scout and tracker, whereby the first evidence of insurgent spoor would be reported to headquarters. ${ }^{59}$ Contact patrols were a function whereby mounted detachments engaged in frequent contact with the local rural populations. ${ }^{60}$ Finally, mounted detachments could act as a mobile reserve force which could be called upon to reach areas at relatively short notice that are inaccessible to vehicles and/or aircraft in the area. ${ }^{61}$

The urgency with which SWATF Command requested horse mounted units and bases in the operational areas is underlined by a communiqué, stemming from a conference held on 16 February 1982 in the High Command Sector One Zero in SWA concerning the discussion of neighbouring Sector Two Zero's 202 Battalion need for horses, dogs and equipment. The conclusions reached at this conference were for the unit organisation of $202 \mathrm{Bn}$. to be adjusted so as to accommodate horse and dog units for operational use, and specifically, the urgent need for the acquisition of two platoons of mounted infantry before April 1983. This included the furnishing of horses and equine related equipment, as well as the training and appointing of a qualified platoon commanding officer, full time veterinarian and farrier. ${ }^{62}$

During Major van Driel's command, his superior, General van Noorden, was asked by the HQ in Windhoek to assist in the establishment of 1 SWASpes Unit. Equestrian Centre became involved in this first purpose- 
built frontline horse and motorcycle mounted infantry base in the Operational Area. 1 SWASpes was established in 1977 at Oshivelo with the first commanding officer being Major David Mentz. ${ }^{63}$ By early 1978, the unit had diversified into the application of motorcycles, trackers and later the introduction of tracking and explosives detection dogs. Mentz was among the first to combine conventional infantry forces on the ground with the skills of trackers, the abilities of dogs and the quick reaction abilities afforded by horses, motorcycle units and paratroopers ${ }^{64}$ Equestrian platoons were detached to bases across the Operational Area, though the main equestrian unit in South West Africa was stationed at Oshivelo. When insurgents did manage to attack bases where horses were often billeted, they did so with small arms fire, rocket propelled grenade, rocket or mortar bombardments. Artillery barrages were something which the mounts could not be sufficiently prepared for in training, and it proved a harrowing experience for the horses. ${ }^{65}$

Efforts were made wherever possible to prevent using horses in direct enemy contact, and battle drills were executed in such a way that when insurgents' spoor got "warmer", patrol commanders would contact nearby a mechanised formation who could take over in hot pursuit. ${ }^{66}$ Depending on the length of patrols conducted, and the frequency at which tracks were discovered, patrols which had covered a distance of some thirty kilometres per day would have been unable to follow hot spoor due to horses' fatigue. Consequently the tactic of transporting patrol sections by means of modified trucks or mine resistant horse transporters, and unloading them at the location of fresh insurgent activity for further pursuit was adopted, ensuring that both the horse and rider were fit to chase the enemy. ${ }^{67}$

Patrols with a duration of one day (as opposed to patrols of seven or even fourteen days) were common and practical along the border 'kaplyn' ${ }^{68}$, allowing horse and rider to be fresher for active duty due to less demanding endurance requirements. The east-west border was divided up into sectors, with units allocated areas of two kilometres long by two hundred metres deep to regularly traverse in search of enemy activity to the point where SADF units entrusted to its security would be so familiar with the terrain that it was simple to see when a new spoor tracked through the area. This was achieved by the expert path-finding abilities of the local Bushmen and Kavango trackers, who were able to detect and interpret the tell-tale signs 
left behind to determine the numbers, physical fitness and capability of SWAPO fighters crossing the frontier. ${ }^{69}$

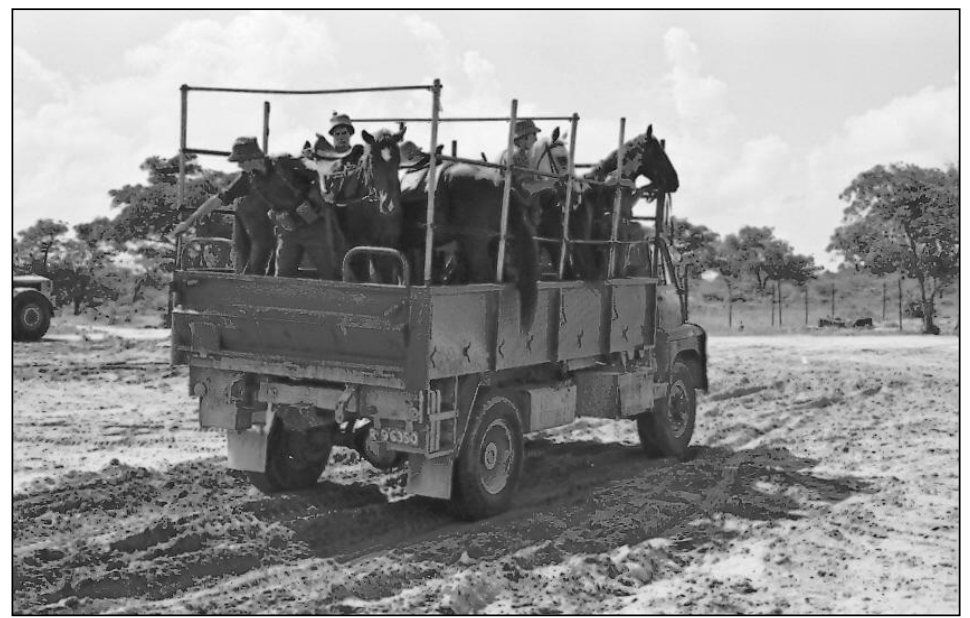

Figure 2: An improvised Bedford Horse transporter truck carrying horses and riders to their patrol jump off point [Source: DOD Archives. Image: 761005999, SADF horse mounted infantry transported in Bedford truck.]

\section{Equine Agency}

As a measure of the important link in familiarity between horse and rider and the rider's ability to interpret unique nuances of his mount, an unnamed commander stationed at 1 SWASpes in 1979 talks of a horse who, while part of a mounted detachment on border patrol, pricked its ears in a specific direction and refused to move forward. On this patrol the trooper was not riding his regular mount, and thus assumed that this horse was simply being stubborn. While reaching out to break off a branch with which to swat his mount, the horse was shot out from under him by SWAPO lying in surrounding ambush positions and in the process of being thrown off his mortally stricken animal, he landed on top of a foe hidden close by. While the subsequent contact resulted in the death of three insurgents, it was posited that if the horses' warnings had been correctly interpreted by the 
rider, the outcome of the contact could have been much different and the unfortunate loss of the horse avoided. ${ }^{70}$ In another incident, horses picketed at a temporary overnight camp on a long distance patrol started to react restlessly at around midnight, in which all the mounts were looking in one specific direction. The sentries took note, informing the commander who in turn immediately ordered his men to dig in against a probable enemy attack. This anticipated attack materialised from the direction in which the horses had been looking and thus took the element of surprise from the enemy. While the outcome of the attack was inconclusive, only three SADF troops were injured. $^{71}$

Personal narratives and oral histories describe the impact of injury or death of mounts on their riders as almost inexpressibly painful and heartbreaking. In the operational environment horses sustained injuries ranging from light injuries such as cuts and scratches, to broken legs, bullet wounds sustained in combat, or the devastating impact upon both horse and rider of the detonation of land mines or the direct impact of a rocket propelled- or rifle grenade. In most cases when injuries were too extreme, regulation dictated that the animal would have to be shot, a task which was shouldered by the mounted infantryman himself, or by a veterinary assistant or medic attached to the patrol. ${ }^{72}$

There were occasions were mounted troops engaged SWAPO insurgents from the saddle, but for the most part they dismounted as soon as the situation became 'hot'. Arno Dreyer concedes that while the elevated vantage point on horseback allows the rider to see farther than their foot soldier counterparts, opponents in prepared ambush positions could have a clearer view of a clearly silhouetted target in the mounted infantryman. This often left the troopers diving for cover from their horses, while still on the move, into the thick undergrowth below. Where mounted detachments worked in cooperation with conventional forces, they did so by preceding the follow-on force of Buffel and Casspir armoured personnel carriers by some five hundred to a thousand meters. ${ }^{73}$

Rifleman Hugo Coetzee indicated to Paratus journalists visiting his mounted unit attached to 116 Battalion that the horses were well trained to adapt to adverse realities of border protection through their time spent at Equestrian Centre. ${ }^{74}$ Nagel emphasised that in a combat situation "you are 
guaranteed to experience small arms fire and in addition perhaps grenade, mortar or artillery bombardment, and the horse, let alone his rider, is a type of animal that will be put to fright by such reports. Despite this, they were trained to tolerate rifle fire from the saddle and fire from adjacent positions by friendly forces, though the whip and crack of incoming fire led them to react differently" 75 Nevertheless, Nagel contended that for ninety five percent of the time he was involved in a contact situation with the enemy, training carried the horse and rider through the situation. ${ }^{76}$ The main objective upon enemy contact was to dismount immediately to address the threat and, when possible, have select members of the section holding the horses while the contact situation unfolded, though combat conditions often prevented this (and the horses would scatter and be recovered later). ${ }^{77}$ Training offered a good foundation, but mounted soldiers needed to be able to improvise and adapt doctrine as the tactical situation demanded.

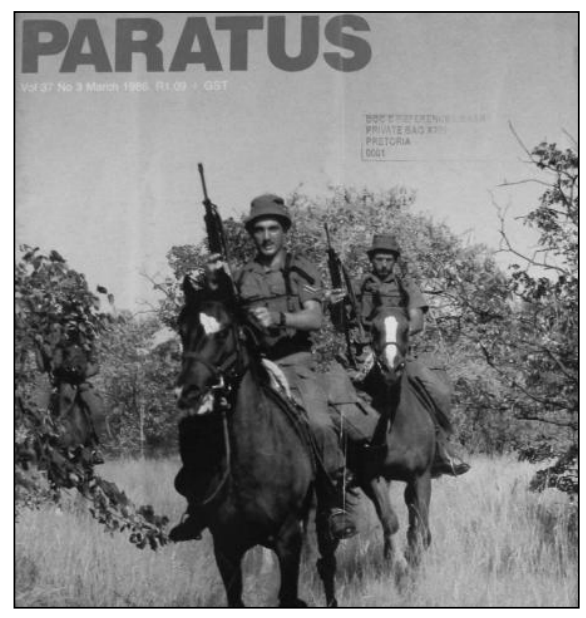

Figure 3: Paratus Vol 37, No 3, March 1986.

In the process of close co-operation with locals such as the Kavango and Bushmen trackers attached to SADF units, many South African mounted troops experienced culture shock, associated with the loss of a horse. In one particular case, Arno Dreyer recounts how while accompanying a patrol, a horse in the section accidentally broke its leg and 
was consequently shot. ${ }^{78}$ While the Corporal to whom the horse had belonged was busy removing its saddle and equipment, the Kavango trackers attached to the patrol began unsheathing their knives with the intention of obtaining its meat, since they deemed it a waste to squander this newly available food source. To the Corporal and his colleagues such action was an outrage, not only because a close member of the team - indeed, a fellow combatant - had been lost, but because the horse was felt to be so equal to these men that there was a sense that "one did not consume one's own." (1899-1902) the enemy's consumption of horses served as useful propaganda, efficacious because the humane treatment of horses was marshalled as the hallmark of civility. ${ }^{80}$ The eating of horses violated the taboo produced by an intimacy that had been increasingly reinforced by shared training and combat, where horses and men relied on each other - it was an act akin to cannibalism.

As Baines has shown, one popular form of "Border literature" or grensliteratuur was illustrated coffee table books. Several books in this genre were published, portraying the military prowess and heroism of the SADF and, especially, the South West African Territorial Force (SWATF): like that of Sonderling, Hooper and Steenkamp's photographic requiem. ${ }^{81}$ Similarly, Peter Badcock's Images of War (1981) offered poems and sketches that paid tribute to the "ordinary" soldier. ${ }^{82}$ The horse-man connection is romanticised in such war doggerel. As in Badcock's

Close your eyes,

Absorb it, your bodies one:

The rich sour-sweet horse smell

And your man-smell one between you. ${ }^{83}$

Badcock's poem "Boer blood", accompanying this sketch below (fig 4), refers to both the blood of the Afrikaans soldier and his Boerperd, suggesting an added kinship between them:

Boer blood quickens in him: 
He rides as his grandfather did

In another time,

On a horse descended,

By some quirk of fate,

From those his grandfather rode.

Badcock's caption to this sketch, "Across the pans" (fig 5), refers explicitly to the "extraordinary bond between horse and rider", capturing a genuine emotion undoubtedly, but also sentimentalizing and thereby glossing over the inherent violence of that which he depicts.

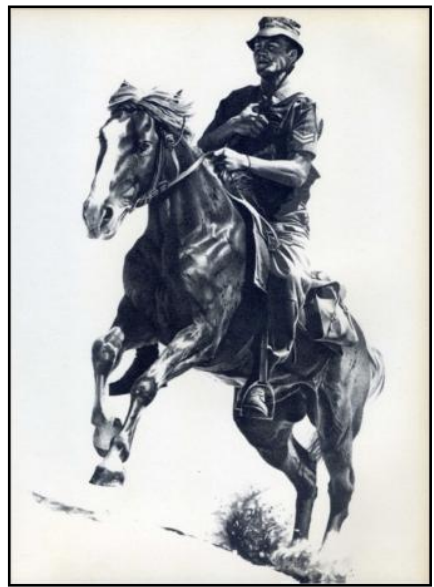

Figure 4: Boer blood

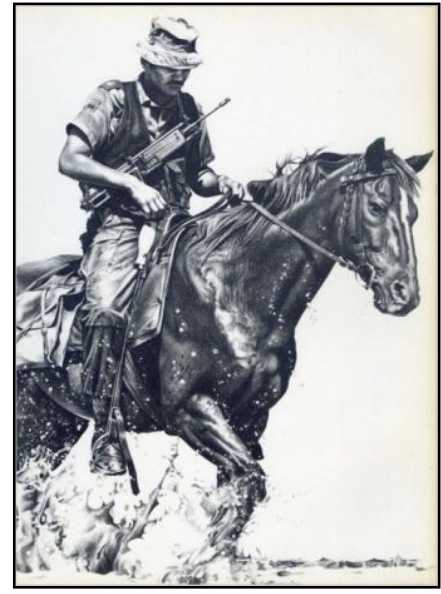

Figure 5: Across the Pan

The horse's relative silence, heightened sensory perception, terrainversatility and speed proved more useful in certain contexts than the foot soldier and armoured vehicles. The ultimate goal of mounted infantry units stationed in SWA was to patrol, track and kill SWAPO insurgents' crossing over the Angola-Namibia frontier. The dynamic internal challenges to the state presented an altogether different application of mounted infantry, which was to see its role change radically from one whose sole raison d'être 
was the use of deadly force, to one which - at least ostensibly - attempted to prevent conflict in the course of its duties.

\section{The State of Emergency in 1985 and Mounted Infantry}

The Apartheid government declared a partial state of emergency in 36 magisterial districts in July $1985 .{ }^{84}$ Growing internal and external opposition to the state caused the government to impose a State of Emergency in 1985 and to re-impose it in 1986. Thus the deployment of the Defence Force in support of the South African Police Service was considered an inevitability by Malan. ${ }^{85}$ Horse mounted infantry detachments, commanded by Major Quinton Painter, were thus deployed to the townships of the Pretoria Witwatersrand Vereeniging (PWV) area during South Africa's State of Emergency in 1985. Painter drew upon the experiences of the Equestrian Centre fraternity, such as Commandant David Mentz of SWASpes, by also integrating elements which were previously not used before by mounted units in the urban areas. This included utilising sniffer dogs, trackers, and calling upon Equestrian Centre's motorcycle mounted troops to work in concert with the more conventional SADF and SAPS formations to command a large, confined area with mobility and stealth. ${ }^{86}$

During operations, the detachment made maximum use of mounted trackers and accompanying dogs that were able to lead them to concealed weapons caches buried by Umkhonto we Sizwe and Azanian Peoples Liberation Army combatants. ${ }^{87}$ To help find these caches, mounted infantry utilised sniffer dogs in a novel way. Major Painter instituted the training of SADF dog handlers in horse riding and selected horses that were "less skittish" (calmer) who could actually carry dogs on their hind quarters. ${ }^{88}$ These dogs were transported on an improvised platform constructed of a crate which was secured behind the saddle and padded with an extra saddle blanket. The dogs were trained to sit on the platform behind the rider while out on patrol, and could remain ready for action.

In SWA the enemy was spread thinly and infiltrated mostly in small groups. On the Border, mounted troops conducted patrols, followed up tracks, acted as cut-off groups, laid ambushes, and in support protected the flanks of formations in larger conventional operations being carried out, with the express purpose of deterring the enemy, and when meeting him, 
engaging with and destroying him. In contrast, in the urban COIN operations launched during the State of Emergency the mounted infantryman and his detachments were seen as a unique display of power. ${ }^{89}$ The psychological effect of between thirty to sixty infantrymen sitting in the saddle, stirrup to stirrup, shoulder to shoulder riding at the gallop in a line abreast formation towards a crowd of protesters below was substantial. ${ }^{90}$ This tactic is reminiscent of the old British cavalry tradition of riding 'knee to knee' at a gallop while using lance and sabre to cut a path through the massed ranks of foot soldiers arrayed before them. ${ }^{91}$

In the informal urban settlement environment where the deployment of the horse mounted units were intended to mitigate bloodshed and scatter potentially disorderly crowds, the tradition of stirrup to stirrup riding was involuntarily resurrected so as to daunt demonstrators and served as an invisible arme blanche to dissipate crowds. Urban COIN in the townships of the PWV was restricted to an area which was more easily cordoned off and patrolled than the vast expanses of the Namibia-Angola border region. ${ }^{92}$

Equestrian Centre's first Company sized unit sent to the PWV area in 1985 was set up at 1 Construction Regiment in Marievale, training troops and mounts for urban COIN, and more specifically in preparation for cross service co-operation with the South African Police Service. Before the mounted unit was committed to the field, controlled exercises were conducted on deserted farms and industrial buildings where mounted troops were acclimatized to their new operating environment. The mounted troops exercised by entering into structures and engaged in house to house clearing under police supervision, actually riding with the horses into some structures. They exposed their horses to thunder-flashes and petrol bombs, discharging firearms so that the horses became accustomed to the noise and smells. ${ }^{93}$ The police made their twelve-berth horse box available to Major Painter's unit, which meant that at any given time the SADF mounted platoon had two twelve berth horseboxes at their disposal as well as one or two trucks that were prepared for transportation at short notice to anywhere on the Rand. ${ }^{94}$

The Training and Employment of Mounted Infantry Manual stated that in the urban role units may be successfully employed in three primary roles. This was applied for the first time on a large scale in 1985, namely through 
the suppression of riotous gatherings, conducting deterrent based street patrols or as checks against the formation of unruly gatherings. ${ }^{95}$ Secondly, mounted units could be used effectively in cordons and searches, maintaining community cordons while also being able to penetrate and assist in actual searches of narrow alleyways and streets barricaded to obstruct the vehicles of the State security forces. Lastly, the mounted infantry was well suited to street patrols ${ }^{96}$, though only in a capacity where the opponent did not conduct its operations very aggressively. The capture and processing of prisoners from horseback was a substantial challenge in the new urban domain. ${ }^{97}$

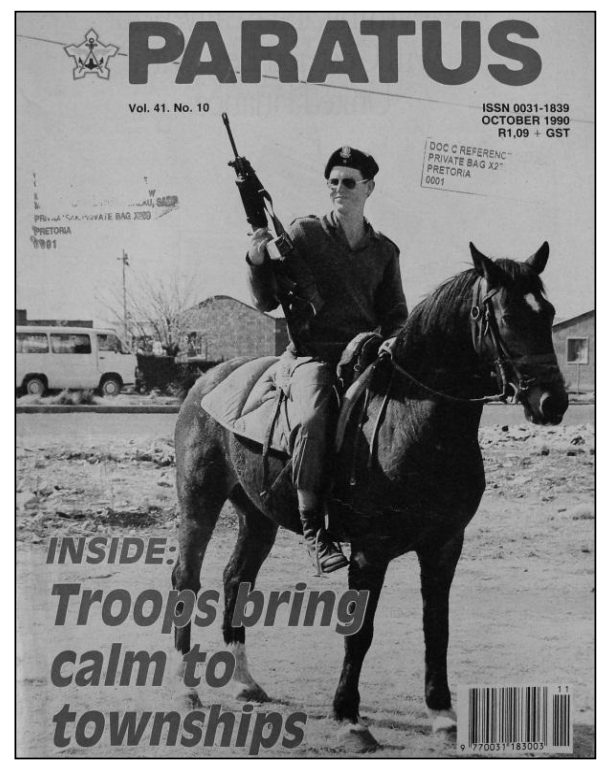

Figure 6: Paratus, Vol. 41, No 10, October 1990.

As historians, however, we must beware the propaganda (see figure 6 above) and romantic representation of these mounted soldiers and the idealized horse-human pairing. Interviewees stated that despite the apparently more benign organic nature of this government force within the overall security apparatus of Apartheid, mounted troops were nevertheless better able to retaliate against civilians - being able to move more silently in 
comparison to the motorised infantry formations and in terrain strewn with obstacles. ${ }^{98}$ Part of the military training these horses and riders had received had conditioned them to run over or through a threat if necessary. ${ }^{99}$ It was, however, not necessary to use excessive violence to deal with crowds in the townships, at least in part because of the symbolic power of horses. ${ }^{100}$ An illustrative example of this occurred at Orlando Stadium where crowds had "necklaced"101 an individual, and in response to this a company of foot soldiers as well as dog units and infantry in armoured vehicles had been deployed there to contain the unrest. In addition, the SADF forces on the scene had requested the assistance of a mounted unit numbering some twenty four horses. Arno Dreyer indicates that the crowd which had up until that point been aggressively stoning some ninety infantrymen, armoured vehicles and police dogs, was quickly dispersed at the appearance of the horse mounted detachment galloping towards them in a line abreast formation. ${ }^{102}$

Where the local population did react against horse mounted infantry and their motorcycle-borne counterparts, they did so with great ingenuity, spanning wire at head and chest height across streets with the aim of decapitating or unseating mounted troops who were in high speed pursuit. ${ }^{103}$ Furthermore, the Training and Employment of Mounted Infantry Manual warned mounted infantrymen of the dangers to their mounts in encountering marbles, nails and grease cast in the path of horses by demonstrators. ${ }^{104}$

Yet, interestingly, horses were infrequently the targets of violence. Painter recalled asking people apprehended by mounted troopers, how horses differed from the other security forces they encountered. This question was posed because it seemed they somehow did not attract the same resentment or hostility from civilians as did other State security entities, such as the police and SADF soldiers. ${ }^{105}$ There was consensus that when the police would deploy into the townships, they did so with their Casspirs, firing rubber bullets and tear gas, and the population experienced it as a highly indiscriminate use of force, with many wounded and frequent fatalities. An incident in the southern part of Soweto involving the first use of tear gas where horses were present offers a telling vignette. In this confrontation with a large gathering of people, following the utilization of tear gas by security forces to disperse the crowd, it was discovered that tear gas did not acutely affect the horses or accompanying dogs, though it did 
have an effect on some riders not quick enough in donning their gas masks. ${ }^{106}$ The word was then seen to spread very rapidly through the townships, "don't mess with the horses". ${ }^{107}$

Moreover, mounted troops would often attempt to talk to community members with the aid of soldiers within the unit who could speak the local language, and through such methods volatile situations were prevented from escalating. One interviewee mentioned to Major Painter that:

When the people with horses came, they were riding just with those berets and things, no armour, no Kevlar jackets or anything, and they would ride right up to a person and greet that person, in the townships, wherever. ${ }^{108}$

The mounted patrols were often confronted with sick animals, dogs, cows, and sheep belonging to members of the community and where possible the operational medic or veterinary orderly treated their injuries. ${ }^{109}$ Major Painter deemed these contact patrols to be highly helpful, saying:

Because of such actions, in subsequent sweeps in places like Soweto and other townships, mounted infantry detachments were more often than not met by people with more of a welcoming gesture than a violent gesture, and injured members of the community or their livestock were brought to the attention of such patrols. ${ }^{110}$

In the subsequent unrest which developed in the townships of the Pretoria Witwatersrand Vereeniging area during 1990, mounted companies were once again called upon for "peace-enforcement". Commandant B. Pos, acting commanding officer of Group 42 deployed to the PWV area, stated that despite logistical challenges horses provided an extremely efficient means to patrol and still could play a vital role in civilian crowd control. ${ }^{111}$

\section{Two sides of the COIN?}

Peter Onoszko has identified mobility, surprise, security and intimidation as advantages provided by horse mounted troops generally. ${ }^{112}$ In the case of the South African Defence Force, these four factors may be further broken down into two groups, namely in the rural COIN role in SWA and the urban COIN role in the PWV during the 1985 State of Emergency. In border patrols, mounted infantry were favoured for their higher vantage point and mobility in being able to cover extensive ground through the horse's 
mobility and endurance when compared to foot soldiers. Moreover, this preserved the soldier's energy for quicker reaction time in the event of enemy contact. Secondly, the comparative silence with which horses move and the speed with which they do so over rougher or inaccessible terrain allow them to more effectively track down an enemy. In the urban surrounds of the townships of the Rand, the security afforded by the horse to the rider through advanced senses and the perspective and the height of the rider allowed him to see further, and in the case of the township setting, specifically to be seen. Endurance was not a substantial factor in the urban environment. Secondly, the element of intimidation reinforced the factors previously mentioned, in that the aspects of intimidation and perception of invincibility played a significant role. As Onoszko argues, the cumulative effect of mobility, surprise and security created in the mind of the opponent a magnified impression of the horse and rider's existing capabilities. ${ }^{113}$

\section{SANDF to SAPS to SANDF?}

With the end of Apartheid and the first democratic elections in South Africa in 1994, the internal role of the newly constituted SANDF and its Equestrian Centre transformed. Defence spending cuts from 1989 onwards saw the closing of Equestrian Centre's horse-breeding unit at De Aar in 1991, and reunited the Bourke's Luck based SANDF Dog Unit with Equestrian Centre in 1993 to form 12 South African Infantry Battalion (12 SAI). ${ }^{114}$ This unit continued to provide horses, motorcycles and dog handlers to Army units in sustained internal COIN, rural security and border protection roles, culminating in the closure of the unit on 1 April 2005. ${ }^{115}$ The Defence Force's responsibility over borders and security in the rural areas was transferred to the South African Police Service. ${ }^{116}$ Consequently, Equestrian Centre Potchefstroom's facility was handed to the SAPS on 14 April 2005, and was renamed as SA Police Service Mounted School Welgegund. ${ }^{117}$

The very visible change over time in the operational capacities of Equestrian Centre, had not escaped the gaze of the South African Police Service, who inherited responsibility for Equestrian Centre from the Defence Force. ${ }^{118}$ In the hands of the South African Police Service, the horse mounted units of metropolitan police forces in cities across South Africa made an essential contribution to public safety, the most notable high profile event being the football fans and international guests from across the 
globe in South Africa for the 2010 FIFA Soccer World Cup. They followed the global trend of using horse mounted police officers for high visibility policing roles. ${ }^{119}$

As noted, the SANDF was due to relinquish responsibility for border security to the SAPS, but in late 2009 the withdrawal of SANDF border units was halted due to security requirements ahead of the World Cup. Afterwards, the responsibility for borderline security was retained by the SANDF under the auspices of Operation CORONA. In resuming borderline security operations, the SANDF has stated that they are under-equipped to conduct these activities. According to Major General B. Hlatshwayo, General Officer Commanding of the Joint Operations Headquarters of the SANDF, force multipliers in the form of high technology, intelligence gathering and specialist infantry forces such as horses, motorbikes and dog handlers were needed to carry out Operation CORONA's mandate of border security, combatting the cross-border movement of illegal immigration, stolen and counterfeit goods, livestock theft, firearms and narcotics trafficking, and the highly publicised scourge of poaching on South Africa's rhino population. ${ }^{120}$

Rumours of negotiations circulated about the SAPS transferring the Welgegund facility back to the SANDF. ${ }^{121}$ DefenceWeb cited Hlatshwayo declaring that the closing of 12 South African Infantry Battalion had proven to be a mistake, and that he was eager to source motorcycle and horse troops for high mobility, border and crowd control purposes. ${ }^{122}$ In December 2011, it was announced that 12 SAI Battalion would be re-formed under the name of 1 Specialised Infantry Reserve Regiment at Potchefstroom, and was urgently seeking out former members of the SADF, Transkei Bophuthatswana Venda Ciskei defence forces, SANDF and non-statutory forces with equestrian, canine, motorcycle, tracking qualifications, farriers, veterinarians and motorcycle mechanics. ${ }^{123}$ In addition, the South African Defence Review 2012, describing the future capabilities of the Army and its Infantry formation, states:

Infantry. The Infantry will engage and destroy the enemy and hold captured ground. Infantry will use infantry combat vehicles, armoured personnel carriers and light vehicles. Rapidly deployable Infantry will be airborne, air-landed and sea-landed. Other special Infantry may use motorcycles and horses. ${ }^{124}$ 


\section{Conclusion}

It has been confirmed by Lieutenant Colonel Jabu Mlotshwa of the South African Army Specialist Infantry Capability (SAASIC) that the aforementioned unit has deployed composite companies constituted of motorcycle and dog equipped troops to South Africa's landward borders as part of the SANDF's Operation CORONA. Those troops who have been trained in horse riding thus far have been deployed alongside in a motorised capacity pending the furnishing of adequate facilities for the upkeep of horses in the area of deployment. In a visit to the unit in Potchefstroom on 13 June 2012, the Chief of the Army, Lieutenant General V.R. Masondo, praised the unit for its quick reaction to the organisational call and rapid deployment to the borders at the end of September 2011 after receiving the first instruction to constitute a capability on 20 April. ${ }^{125}$ The historical experiences of Equestrian Centre and SWASpes suggest that just as the regional political situation dictated the utilisation and adaptation of horse mounted units in the past in the operational areas, the SANDF today sees a renewed and flexible role for horse mounted troops, one that once again is given extra momentum by the visible support of the Chief of the South African Army.

Thus, the horse mounted rifle is envisaged once more as a potential element within the infantry. The recovery of the knowledge, riders and mounts lost after the closing of Equestrian Centre will not be easy or inexpensive to replace. Nevertheless, it has been demonstrated - through growing support from within Defence Force circles and also operational need - that expertise exists within its ranks and (as history shows) may be developed, to re-initiate and sustain this specialist entity.

Thanks to Arno Dreyer, Lindy Heinecken, Jakobus Nagel, Bill Nasson, Joanine Nel, Quinton Painter, Albert van Driel, Riaan Verster, Graham Walker, as well as the Equestrian Centre / SWASpes community.

The terms Border War (Grensoorlog) and Bush War (Bosoorlog) were used loosely, of the conflict in northern Namibia and operations in Angola. Baines has pointed out that the "Border" had both literal and symbolic meanings. To the SADF it represented the operational zone where the SADF and the South West African Peoples' Organisation (SWAPO), known as the People's Liberation Army of Namibia (PLAN), clashed. The acceptance of the nomenclature - "the Border War" - by (most of the) white civilians denoted 
belief in official Apartheid rhetoric. Gary Baines, “'South Africa's Vietnam'? Literary History and Cultural Memory of the Border War", South African Historical Journal, 2003, 49:1, 172-192. See also Gary Baines, "Vietnam Analogies and Metaphors: The Cultural Codification of South Africa's Border War". Safundi, 2012, 13:1-2, pp. 73-90. For more on the idea of a border, see D. Conway, 'Somewhere on the Border - of credibility': the cultural construction and contestation of 'the Border' in white South African society. IN: Baines, G. and Vale, P. (eds). Beyond the Border War: new perspectives on Southern Africa's late-Cold War conflicts. (Pretoria: University of South Africa Press, 2008), pp. 75-93.

See Janet Cherry, Umkhonto WeSizwe (Auckland Park: Jacana, 2011), from p.87 onwards.

Magnus Malan, My Life with the SA Defence Force. (Pretoria: Protea Book House, 2006), p. 56.

Ibid, p. 57.

Sandra Swart, Riding High: Horses, History and Humans in South Africa (Johannesburg, Witwatersrand University Press, 2010) p.27.

Formerly called Roberts Heights, the military complex at Voortrekkerhoogte today is named Thaba Tshwane.

SANDF Department of Defence Pretoria Archive Group: Unit History 12 SAI. Description: Unit History: 12 SAI Bn. Period: 30 January 2007.

Ibid.

Department of Defence Archives (DOD), SADF Equestrian Centre Telex, Part 00.

The Commandant was joined soon after by Major Peter Stark as chief instructor of the equitation wing and Captain Leon Wessels in charge of the tactical wing. Annual Historical Report. Unit: SADF Equestrian Centre. Corps: SA Infantry Corps. Command: North West Command. Period: 31 December 1975.

DOD Archives, Historiese Oorsig van die SAW Beredesentrum, p. 1. DOD Archives. Image 871000265: AANWENDING VAN PERDE DEUR DIE SAW.

Oral History Interview: Regimental Sergeant Major (ret) Jakobus Nagel. Date of Interview: $14^{\text {th }}$ October 2010.

From the Afrikaans word 'Spesialiste' fused with 'Suid Wes Afrika', SWASpes grew out of 101 Specialist Unit, formed at Oshivelo in 1977 to centralise disparate reaction forces, combining paratroopers of 1 Parachute Battalion with dog handlers, trackers, mounted infantry as well as a motorcycle platoon.

COIN is defined as "those military, paramilitary, political, economic, psychological and civic actions taken by a government to defeat insurgency (an organised movement aimed at the overthrow of a constituted government through the use of subversion and armed conflict)". See US Department of Defense Dictionary of Military and Associated Terms, http://www.dict.mil/doctrine/jel/doddict. Accessed 12 January 2012.

For this long historical legacy, see Swart, Riding High, pp. 122, 123. 
K. Van Vuuren, "Die Plaasseuns laat Terroriste Sidder", Landbou Weekblad, 22 June 1979, p. 9.

Emphasis added.

Murray Hickling, Chocolate Soldier (An Equestrian Rifleman's Story), http://sadf.sentinelprojects.com/bg2/CHOCOL.html, Published: 26 March 2003, accessed 1 July 2010.

Perdeskoen Beredesentrum Jaarblad, Jaargang 7, (Pretoria: 1 Militere Druk Eenheid, 1989), p. 11.

P. Stark, Die Wit Boesman (Pretoria: Protea Boekhuis, 2008). pp. 35, 112.

Ibid. Magnus Malan served as Head of the Army from 1973 to 1976 and as Chief of the SADF from 1976 to 1980, Jannie Geldenhuys served as Head of the Army from 1976 to 1980 and Chief of the SADF from 1980 to 1985.

Opleiding en Aanwending van Berede Infanterie: Volume 1 (Pretoria: 1 Militere Druk Eenheid, 1978), p. i.

Ibid.

During his 1980-1984 command at Potchefstroom , most mounted operations took place to combat SWAPO.

During the period 1984-1989 the contributions of Commandants Nic Ackerman, Quinton Painter and Nanti Potgieter were pivotal, both in the planning phase and in actual application of horse mounted troops in the townships. Perdeskoen Beredesentrum Jaarblad, Jaargang 7, (Pretoria: 1 Militere Druk Eenheid, 1989), p. 51.

Ibid., p. 50.

M. Malan, My Life with the SA Defence Force (Pretoria: Protea Book House, 2006), p. 227.

Oral History Interview: Lieutenant Colonel (ret) Albert van Driel. Date of Interview: 15th September 2010.

Ibid.

Ibid. In fact, The McClellan saddle was designed by a United States army officer and adopted by their military in 1859 and used until mid-twentieth century.

Ibid.

Oral History Interview: Brigadier General (ret) Quinton Painter. Date of Interview: $17^{\text {th }}$ September 2010.

Oral History Interview: Lieutenant Colonel (ret) Albert van Driel.

Ibid.

Standard issue combat helmet. Literally translated from Afrikaans to mean 'Steel Roof'.

Oral History Interview: Corporal (ret) Riaan Verster. Date of Interview: $13^{\text {th }}$ October 2010.

Oral History Interview: Regimental Sergeant Major (ret) Jakobus Nagel.

Perdeskoen Beredesentrum Jaarblad, Jaargang 7, (Pretoria: 1 Militere Druk Eenheid, 1989), p. 49.

Oral History Interview: Regimental Sergeant Major (ret) Jakobus Nagel.

Ibid.

Oral History Interview: Lieutenant Colonel (ret) Albert van Driel. 
SANDF Department of Defence Pretoria Archive Group: 1 SWA Specialise Eenheid. Serial No. 1. Box 24. File reference no. 405 / 1 / 32 / 1 / 1 / 09331.

Oral History Interview: Sergeant Major (ret) Arno Dreyer. Date of Interview: 11th October 2010.

SANDF Department of Defence Pretoria Archive Group: 1 SWA Specialise Eenheid. Serial No. 1. Box 24. File reference no. 405 / 1 / 32 / 1 / 1 / 09331. Description: Perde: Behoefte Opname, Voeding van SAW Perde. Vol. 1. Period: 19th January 1983.

Opleiding en Aanwending van Berede Infanterie: Volume 3 - Basiese Rykuns (Pretoria: 1 Militere Druk Eenheid, 1984), p. 2-1.

A word used by the Owambo of Northern Namibia to denote wide open grassland.

Oral History Interview: Sergeant Major (ret) Arno Dreyer.

M. Norval, The Bush War Heats Up, Death in the Desert: The Namibian Tragedy (Washington D: Selous Foundation Press, 1989). p. 120.

Oral History Interview: Sergeant Major (ret) Arno Dreyer.

Translated from Afrikaans means 'track' or 'sign', denoting the tell-tale evidence left behind by infiltrating insurgents' boot-soles and also disturbed terrain and vegetation

SANDF, Department of Defence Pretoria Archive Group: 1 SWA Specialise Eenheid. Serial No. 1. Box 24. File reference no. 405/1/32/1. Description: Perde: Behoefte Opname, Voedingsverslag vir die periode 1 April 1981 tot 30 April 1981. Vol. 1. Period: 14 ${ }^{\text {th }}$ May 1981.

Logistics Battalion.

SANDF, Department of Defence Pretoria Archive Group: 1 SWA Specialise Eenheid. Serial No. 1.File reference no. 402 / 1 / 32 / 1. Description: Bestuur van Kommoditeite, Perde Voer. (TEFF). Vol. 1. Period: 16 October 1979.

Opleiding en Aanwending van Berede Infanterie: Volume 1. (Pretoria: 1 Militere Druk Eenheid, 1978), p. 1-7.

Ibid.

Ibid.

Ibid.

This was deemed vital, as commanders like Magnus Malan and Jannie Geldenhuys attached great significance to acquiring the cooperation of the local population. The idea of "winning hearts and minds" included variously burgersake (civic action), komops (communication operations), ploeg en plant (plow and plant) and psy-ops (psychological operations). Opleiding en Aanwending van Berede Infanterie: Volume 1. (Pretoria: 1 Militere Druk Eenheid, 1978) p. 1-8.

SANDF Department of Defence Pretoria Archive Group: 1 SWA Specialise Eenheid. Serial No. 1. Box 24. File reference no. 405 / 1 / 32 / 1 / 1 / 09331. Description: Perde: Behoefte Opname, Operationele Aanwending van Perde en Honde. Vol.1. Period: $11^{\text {th }}$ March 1982.

Oral History Interview: Lieutenant Colonel (ret) Albert van Driel.

R. H. Heittman, Modern African Wars (3) South West Africa (Men at Arms Series; No. 242). (Great Britain: Osprey Publishing, 2005), p. 20.

Oral History Interview: Lieutenant Colonel (ret) Albert van Driel. 
Ibid.

Ibid.

Translated from Afrikaans means 'Cut-line' denoting the vegetation denuded section of the SWA-Angola border maintained by the SADF.

Oral History Interview: Sergeant Major (ret) Arno Dreyer.

K. Van Vuuren, "Die Plaasseuns laat Terroriste Sidder," Landbou Weekblad. 22 June 1979, p. 17.

Ibid.

P. B. G. Delmar, "The vital role played by mounted soldiers," Paratus, March 1986, p. 41.

P. W. J. Onoszko, Horse-Mounted Troops in Low Intensity Conflict (Carlisle Barracks, PA: U.S. Army War College, 1991), p. 20.

P. B. G. Delmar, "The vital role played by mounted soldiers," Paratus, March 1986, p. 41.

Oral History Interview: Regimental Sergeant Major (ret) Jakobus Nagel.

Ibid.

Ibid.

Oral History Interview: Sergeant Major (ret) Arno Dreyer.

Ibid.

Swart, Riding High, 132 and Sandra Swart, "Horses in the South African War, c.1899-1902", Society \& Animals, 18. 4, 2010.

S. Sonderling, Bushwar (Windhoek, 1980); J. Hooper, Koevoet (Johannesburg, 1988), and W.Steenkamp, South Africa s Border War 1966-1989 (Gibraltar, 1989). For discussion, see Casper Erichsen, 'Shoot To Kill': Photographic Images in the Namibian Liberation / Bush War". Kronos, No. 27, 2001, pp. 158-182.

Gary Baines, "Breaking Rank: Secrets, Silences and Stories of South Africa's Border War". See David Maugham-Brown, 'Images of War: Popular Fiction in English and the War on South Africa's Border', The English Academy Review, vol. 4, 1987, pp. 53-66. Peter Badcock, Images of War, Durban: Graham Publishing, 1981. For an exploration of masculinity "on the border" see Jennifer Rees, "Masculinity and Sexuality in South African Border War Literature", MA, University of Stellenbosch, 2010.

Badcock, Images of War.

Magnus Malan, My Life with the SA Defence Force (Pretoria: Protea Book House, 2006), p. 322

Ibid, p. 326.

Oral History Interview: Lieutenant Colonel (ret) Albert van Driel.

Oral History Interview: Brigadier General (ret) Quinton Painter. Date of Interview: $17^{\text {th }}$ September 2010.

Ibid.

Oral History Interview: Regimental Sergeant Major (ret) Jakobus Nagel. Ibid.

Sandra Swart, Riding High: Horses, History and Humans in South Africa (Johannesburg: Witwatersrand University Press, 2010), p. 105.

Oral History Interview: Regimental Sergeant Major (ret) Jakobus Nagel.

Oral History Interview: Brigadier General (ret) Quinton Painter. 
Account of Equestrian Centre / Operations: Brigadier General (ret) Quinton Painter.

Opleiding en Aanwending van Berede Infanterie: Volume 1. (Pretoria: 1 Militere Druk Eenheid, 1978), p. 1-7.

Ibid.

Ibid. p. 1-8.

Oral History Interview: Lieutenant Colonel (ret) Albert van Driel.

Oral History Interview: Sergeant Major (ret) Arno Dreyer.

Ibid.

Act whereby an individual is restrained and subjected to a gruesome death by fire by placing a petroleum doused rubber car tyre around their neck and igniting it.

Oral History Interview: Sergeant Major (ret) Arno Dreyer.

Ibid.

Opleiding en Aanwending van Berede Infanterie: Volume 1. (Pretoria, 1 Militere Druk Eenheid, 1978), p. 1-8.

Ibid.

Oral History Interview: Brigadier General (ret) Quinton Painter.

Ibid.

Oral History Interview: Brigadier General (ret) Quinton Painter.

Ibid.

Ibid.

R. Torr, "Troops bring calm to townships," Paratus, October 1990, p. 40.

P. W. J. Onoszko, Horse-Mounted Troops in Low Intensity Conflict (Carlisle Barracks, PA: U.S. Army War College, 1991), p. 20. p. 3.

Ibid, p. 5.

L. Engelbrecht, "Satellites, gyrocopters \& non lethal weapons needed to secure borders". defenceWeb. 23 August 2010.

<http://www.defenceweb.co.za/index.php?option=com content $\& v i e w=a r t i c l e$ \&id=9342: satellites-gyrocopters-a-non-lethal-weapons-needed-to-secureborders\&catid=55:SANDF \&Itemid $=108>$ 2012.

K. Geldenhuys, "New Premises for the SAPS Mounted School," Servamus . 30 June 2005. p. 38.

Ibid. SAPA Correspondent. "Potch Special Unit Disbanded". News24 Online, 30 March 2005. <http://www.news24.com/SouthAfrica/News/Potch-specialunit-disbanded-20050329>

Accessed on 23 September 2009.

K. Geldenhuys, "New Premises for the SAPS Mounted School," Servamus . 30 June 2005. p. 38.

Ibid.

City News, the Newsletter for the Residents of Cape Town, "The six-legged cops' big advantage," March 2010, Issue 25, p. 7.

L. Engelbrecht, "Satellites, gyrocopters \& non lethal weapons needed to secure borders". defenceWeb. Accessed on 23 August 2010.

E. Gibson, "Perde en honde terug na die grens". Die Beeld, 18 July 2011. <http://152.111.1.88/argief/berigte/beeld/2011/07/18/B1/10/teg12sai.html $>$ Ac cessed on: 20 October 2011. 
122 L. Engelbrecht, "Satellites, gyrocopters \& non lethal weapons needed to secure borders". defenceWeb. 23 August 2011.

123 SANDF Correspondent. "12 SAI Comes Back to Life". Potchefstroom Herald, 16 December 2011. 14.

124 South African Defence Review 2012 Draft Document for Public Engagement. 12 April 2012. p. 277.

125 South African Department of Defence Press Statement. "Chief of South African Army Thanks Specialist Infantry Capability For its Hard Work and Dedication”. 27 June 2012. Accessed 04 August 2012. <http://www.army.mil.za/news/news\%202012/jun_12/c_army thanks_speciali st_inf_capability.htm>Accessed on: 04 August 2012. 